\title{
Effects of a single-entry intake system on access to outpatient visits to specialist physicians and allied health professionals: a systematic review
}

\author{
Milica Milakovic MSc, Ann Marie Corrado MSc, Mina Tadrous PharmD PhD, Mary E. Nguyen BSc, \\ Sandra Vuong MSc, Noah M. Ivers MD PhD
}

Abstract

Background: Canada lags behind other countries with respect to wait times for specialist physician and allied health professional consultations. We conducted a systematic review to assess the effects of a single-entry model on waiting time, referral volume and the satisfaction of patients and health care providers.

Methods: We searched MEDLINE, Embase, Cochrane CENTRAL and CINAHL databases from inception to December 2019. We included studies from countries in the Organisation for Economic Co-operation and Development that reported on the effects of a single-entry model on the time between referral to first assessment by a specialist physician or allied health professional, termed wait time 1 (WT1). Patient volume and the satisfaction of providers and patients were secondary outcomes. We conducted a narrative synthesis using descriptive statistics.

Results: Of the 4637 citations identified, 17 met the eligibility criteria, and we included 10 of these in the final analysis. All of the included studies reported an absolute reduction in WT1 after implementation of the single-entry model. The average percent reduction in WT1 across specialties was greatest for surgical referrals (57\%) and urgent internal medicine referrals (40\%). Higher initial WT1 was associated with a greater absolute reduction in WT1 after implementation of the single-entry model $(p=0.002)$. Patient and provider satisfaction with the single-entry model was high in all studies. The effect estimates from all included studies were at high risk of bias.

Interpretation: Single-entry models were associated with an absolute reduction in time from referral from primary care to consultation. These models represent a promising option to improve access to a range of health services, but there is a need for rigorous prospective evaluations to inform policy. PROSPERO Registration: CRD42018100395

$\mathrm{P}$ oor access to specialist physicians and allied health professionals (hereafter referred to as "specialists") and long wait times are pervasive problems facing many health care systems. ${ }^{1}$ Relative to its international peers, Canada struggles to provide timely access to care. ${ }^{2}$ Canadian wait times between referral and appointment are twice as long as they were 25 years ago, increasing from an average of 9.3 weeks in 1993 to 19.8 weeks in $2018 .^{3}$ Currently, most outpatient clinicians use a "multiple-queue, multiple-server" model to manage their referrals and wait lists, whereby each clinician has a separate queue. ${ }^{4}$ As such, clinicians of the same specialty, working in the same region, may have different approaches to managing referral and wait lists, potentially leading to inequitable and suboptimal patient outcomes. In contrast, single-entry models assemble patients referred to specific specialists in a given jurisdiction into a single queue, thereby allowing each patient to see the first available specialist. The single-entry model consists of a centralized intake (i.e., referrals are received through a single point of entry) or a pooled referral system (i.e., merging of multiple waiting lists), along with a centralized, coordinated approach to triage (i.e., appointments arranged according to urgency). ${ }^{5}$

The single-entry model is based on queuing theory ${ }^{6}$ and has been proven successful in operational fields such as the airline industry. ${ }^{5}$ In health care, the benefits of this model are thought to relate to rebalancing of supply (i.e., clinician availability) and demand (i.e., the number of referrals). ${ }^{4}$ In addition, sicker patients may be seen faster with a central intake system, whereby the patient is referred to an available provider according to urgency. Although single-entry models may prevent duplicate and cancelled appointments, they may also limit choice and reduce satisfaction. ${ }^{4} \mathrm{~A}$ prior review

\section{Competing interests: None declared.}

This article has been peer reviewed.

Correspondence to: Milica Milakovic, milica.milakovic@mail.utoronto.ca CMAJ Open 2021. DOI:10.9778/cmajo.20200067 
suggested that this model may reduce wait times for surgeries. ${ }^{5}$ However, that review included only referrals to surgical specialties and measured waiting time from consultation to surgery (also known as "wait time 2"), as well as overall wait time from referral to surgery. ${ }^{5}$

Here, we evaluated the effect of implementation of a single-entry model on the wait time from initial referral (typically from primary care) to consultation with any specialist physician or allied health professional (also known as "wait time 1" [WT1]), as well as measuring overall referral volume and the satisfaction of both patients and providers, because these outcomes were deemed to have the highest priority for policy-makers.

\section{Methods}

We followed the PRISMA guidelines for reporting, ${ }^{7}$ and this review was registered on PROSPERO (CRD42018100395). The only protocol amendment for this study was that we considered for our systematic review single-entry models related to allied health professionals, as well as those involving specialist physicians. The complete PICO (population, intervention, comparison, outcome) research questionnaire can be found in Appendix 1 (available at www.cmajopen.ca/ content/9/2/E413/suppl/DC1).

\section{Literature search}

Three of the authors (M.M., M.E.N., S.V.) independently conducted a systematic literature search of the following databases, from inception to December 2019: Medical Literature Analysis and Retrieval System Online (MEDLINE, Ovid, from 1946), Excerpta Medica database (Embase, Ovid, from 1947), Cochrane Central Register of Controlled Trials (CENTRAL, from 1999) and Cumulative Index to Nursing and Allied Health Literature (CINAHL, EBSCO, from 1937). The reviewers searched all keywords and mapped them onto subject headings where appropriate. To ensure completeness, we also screened the reference lists of all included articles for additional articles and cross-referenced against the references included in a 2017 review on the same subject by Damani and colleagues. ${ }^{5}$ We extended the search from that conducted by Damani and colleagues ${ }^{5}$ (which focused on referral to elective surgery) to include appointments with specialist physicians and allied health providers. The full search strategy for MEDLINE is provided in Appendix 2 (available at www.cmajopen.ca/content/9/2/E413/suppl/DC1). We did not restrict the search to any particular language, and we modified the search strategy appropriately for each database. We did not extend the search to include grey literature.

\section{Study selection}

We excluded duplicates from the search results before screening. Three reviewers (M.M., M.E.N., S.V.) conducted the title and abstract screening, followed by full-text review. The reviewers independently screened all search results and then compared their individual results. They resolved discrepancies through consensus or by consulting the senior author (N.M.I.).
We included original studies that met all of the following inclusion criteria: inclusion of outpatients who were referred to specialists for medical, surgical or allied health services; implementation of a single-entry model; and measurement of the wait time from referral to the specialist appointment (WT1), both before and after implementation of the singleentry model. ${ }^{5}$ We included only studies that reported the absolute (not relative) reduction in WT1 after implementation of the single-entry model. Given the paucity of evidence in this field of study, we included conference abstracts as reviewed articles, although we did not combine their findings with the results of other studies for the purpose of statistical analysis.

We excluded studies that did not report original data. To facilitate generalizability within the Canadian health care system, we excluded studies conducted in countries other than those of the Organisation for Economic Co-operation and Development (OECD). ${ }^{8}$ The choice of OECD countries was based on the following rationale. Single-entry models are most likely to be effective in situations where there are multiple specialists with different waiting lists in the same catchment area. Although single-entry models could be helpful in low- and middle-income countries, the mechanism may be slightly different in those settings, which often lack adequate health care human resources.

\section{Data collection}

Two reviewers (M.M., A.M.C.) independently collected the data and then compared their individual results. We considered the following study variables: first author, year of publication, country of implementation, specialty setting, health care setting (i.e., private v. public), insurance mandate (i.e., single payer v. multiple payers), study design, type of singleentry model (central intake, centralized approach to triage, pooled referral system), sample size, implementation process, implementation fidelity (i.e., how research teams ensured uptake and ongoing use of the new approach, the "degree of adherence to the described implementation strategy" $)$ and whether the study was reporting on optional or mandatory implementation. Collected outcome data included WT1 before and after implementation of the single-entry model, as well as changes in patient volume and changes in patient and provider satisfaction. We contacted the corresponding authors of individual studies by e-mail to request any data that were missing from the published report; however, despite these efforts, the sample size was not available for 3 of the included studies. ${ }^{10-12}$ Any discrepancies were resolved though consensus.

\section{Risk of bias}

We used the Risk of Bias in Nonrandomized Studies of Interventions tool to assess quality and risk of bias of the included studies. This tool was specifically designed to assess risk of bias in nonrandomized studies comparing the effects of 2 or more interventions. ${ }^{13} \mathrm{We}$ assessed the risk of bias using all 7 domains of the tool. For each domain, 2 reviewers (M.M., A.M.C) conducted the risk-of-bias assessment 
according to the following scale: low, moderate, serious, critical or no information. They also assessed the risk of bias related to study funding and conflicts of interest. The reviewers resolved any discrepancies through consensus or by consulting the senior author (N.M.I.).

\section{Statistical analysis}

For all study characteristics and outcomes (such as wait times and satisfaction of patients and physicians), we report the data as arithmetic means, frequencies or proportions, as appropriate, using medians as measures of central tendency when means were not available. We report all numeric values with the same number of significant figures as reported in the original studies. For data obtained from figures, we extracted the preimplementation values at last follow-up for comparison with post-implementation data at last follow-up. We recorded standard deviations at the level of the study cohort and converted interquartile ranges into standard deviations if appropriate.

We defined the exposure as implementation of a singleentry model and the outcome of interest as the absolute reduction in wait time after implementation of the singleentry model. We investigated the relation between baseline WT1 and absolute reduction in WT1 using the coefficient of determination based on a linear relation, as well as a univariable linear regression. If there were multiple possible values for pre- and post-implementation WT1, we chose the earliest pre-implementation and latest post-implementation values, to avoid the collection of artificial data that could be attributable to the immediate peri-implementation period. We included $p$ values if they were reported, with $p$ values less than 0.05 considered statistically significant.

We used Excel (Microsoft Corporation) to compile the data and SPSS Statistics, version 23 (IBM), to analyze the data. Meta-analysis was not possible, given the lack of available information and the difference in reporting of results across the included studies.

\section{Ethics approval}

Given the nature of the study design, ethics approval was not required.

\section{Results}

Of the 4637 citations identified, 17 met the eligibility criteria, and 10 were included in the final analysis, ${ }^{6,10-12,14-19}$ (Figure 1). Seven articles ${ }^{20-26}$ were excluded from full-text screening.

\section{Study characteristics}

Table 1 summarizes the characteristics of the included studies. Eight studies were from Canada, ${ }^{6,10,11,14-18} 1$ study was from Australia, ${ }^{19}$ and 1 study was from England. ${ }^{12}$ The studies were published between 2004 and 2017, with most published after 2010. ${ }^{6,11,16-19}$ Overall, 9 articles used a simple comparative study design (pre-implementation v. post-implementation), ${ }^{6,10-12,14,15,17-19}$ and 1 was cross-sectional. ${ }^{16}$

The setting for evaluation of a single-entry model was surgery (orthopedics and general surgery) in 3 studies, ${ }^{10,12,16}$

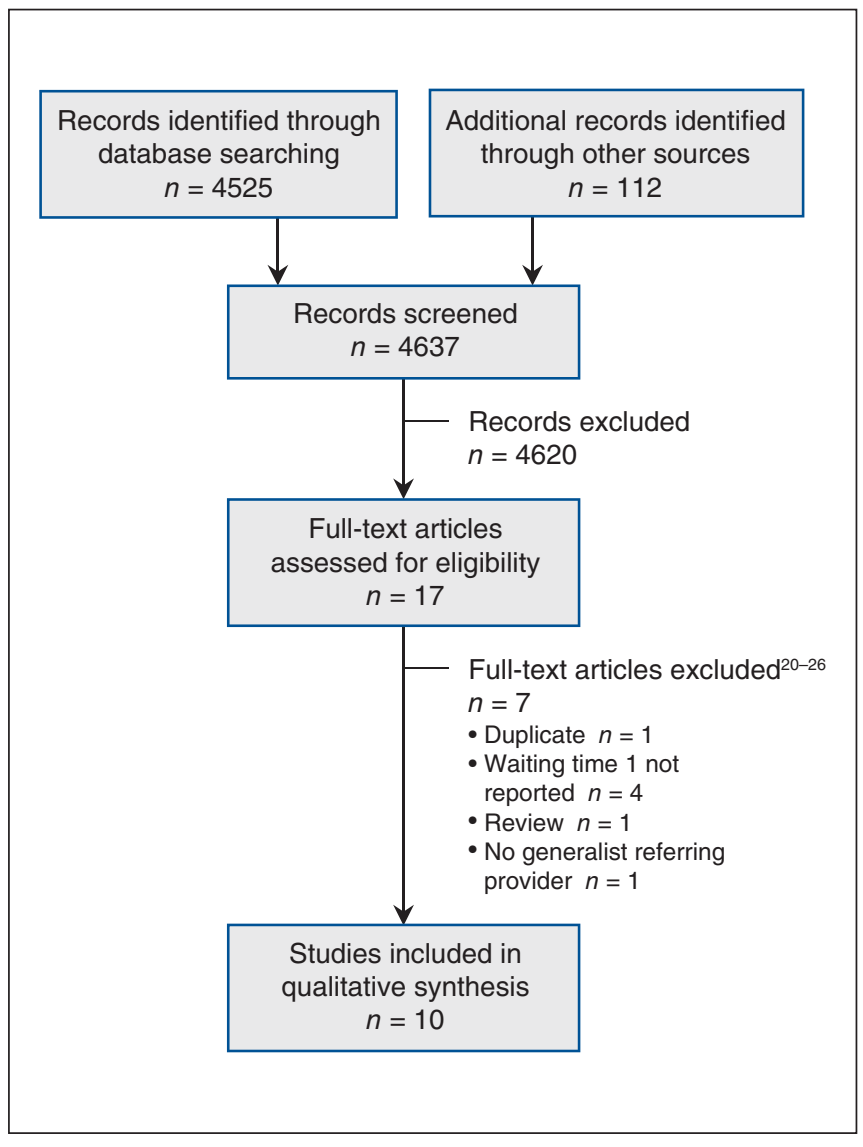

Figure 1: PRISMA flow diagram.

internal medicine (gastroenterology, rheumatology, cardiology, general internal medicine and nephrology) in 5 studies, ${ }^{6,14,15,17,19}$ chronic pain in 1 study $^{11}$ and physiotherapy in 1 study. ${ }^{18}$ All but one of the studies were conducted in a single-payer health care system, ${ }^{6,10-12,14-18}$ the exception involving a 2 -tier system. ${ }^{19}$ Three studies required mandatory implementation of a single-entry model, ${ }^{14,18,19}$ whereas 7 reported on optional implementation. ${ }^{6,10-12,15-17}$

The implementation process for the single-entry model was described in all studies; however, implementation fidelity was described in only 3 articles. ${ }^{6,10,16}$ Nine of the studies used quantitative analysis, ${ }^{6,10-12,14-17,19}$ and 1 study used a mixed-methods approach. ${ }^{18}$

\section{Risk of bias}

The effect estimates from all included studies were at high risk of bias (Table 2). Eight of the included studies had an overall serious risk of bias, ${ }^{6,11,12,14,15,17-19}$ and 2 studies had a critical risk of bias. ${ }^{10,16}$ There was serious or critical risk of bias in the following categories: confounding $(n=10)$, selection of participants for the study $(n=1)$ and missing data $(n=1)$. Three categories generally had low risk of bias: classification of intervention $(n=10)$, measurement of outcome $(n=8)$ and selection of the reported results $(n=8)$. One study reported high risk of bias for conflicts of interest, ${ }^{16}$ and no studies reported high risk of bias for funding. 


\begin{tabular}{|c|c|c|c|c|c|}
\hline $\begin{array}{l}\text { Reference } \\
\text { (year) and } \\
\text { country }\end{array}$ & Study design & $\begin{array}{l}\text { Sample } \\
\text { size }\end{array}$ & $\begin{array}{l}\text { Health system } \\
\text { and specialty } \\
\text { setting }\end{array}$ & $\begin{array}{c}\text { Characteristics } \\
\text { of SEM }\end{array}$ & Implementation process and fidelity \\
\hline $\begin{array}{l}\text { Leach et al. } \\
(2004),{ }^{12} \\
\text { England }\end{array}$ & $\begin{array}{l}\text { Simple pre-post with } \\
\text { non-equivalent group, } \\
\text { time series }\end{array}$ & NA & $\begin{array}{l}\text { Single payer, } \\
\text { surgery: spinal }\end{array}$ & $\begin{array}{l}\text { Pooled list, } \\
\text { optional }\end{array}$ & $\begin{array}{l}\text { A managed generic waiting list was implemented for } \\
\text { initial outpatient appointment and subsequent surgery, } \\
\text { and a computerized MRI booking system was integrated } \\
\text { with outpatient follow-up appointments. As part of the } \\
\text { managed generic waiting list, a consultant screened all } \\
\text { new outpatient GP spinal referrals to assess suitability for } \\
\text { a pooled waiting list, and patients were referred to next } \\
\text { available physician. Same process was applied for } \\
\text { managed generic waiting list for surgery. } \\
\text { Implementation fidelity: NA }\end{array}$ \\
\hline $\begin{array}{l}\text { Bichel et al. } \\
\text { (2009), },^{14} \\
\text { Canada }\end{array}$ & $\begin{array}{l}\text { Simple pre-post with } \\
\text { no equivalent groups, } \\
\text { time series }\end{array}$ & $\begin{array}{c}8289 \\
\text { patients }\end{array}$ & $\begin{array}{l}\text { Single payer, } \\
\text { internal medicine }\end{array}$ & $\begin{array}{c}\text { Central access } \\
\text { and triage, } \\
\text { mandatory }\end{array}$ & $\begin{array}{l}\text { The conference model preceded and allowed for } \\
\text { development and implementation of the central access } \\
\text { and triage system. The latter involved pooling referrals by } \\
\text { specialty, using standardized information requirements } \\
\text { and policy for confirmation of receipt of referral, as well as } \\
\text { for acceptance of appointment. Wait times were } \\
\text { measured in weeks to appointment, based on triage } \\
\text { priority. } \\
\text { Implementation fidelity: NA }\end{array}$ \\
\hline $\begin{array}{l}\text { Bungard et al. } \\
\text { (2009), },^{15} \\
\text { Canada }\end{array}$ & $\begin{array}{l}\text { Simple pre-post with } \\
\text { non-equivalent } \\
\text { groups, time series }\end{array}$ & $\begin{array}{c}3096 \\
\text { patients }\end{array}$ & $\begin{array}{l}\text { Single payer, } \\
\text { cardiology }\end{array}$ & $\begin{array}{l}\text { Single point of } \\
\text { entry, optional }\end{array}$ & $\begin{array}{l}\text { Cardiac EASE (January 2004-December 2006) was the } \\
\text { single-point-of-entry model. Referrals were tracked } \\
\text { through the MedTech database. All referrals were sent via } \\
\text { fax to a single EASE intake service location and reviewed } \\
\text { by EASE NP. Patients and referring FP were offered the } \\
\text { choice of enrolling in EASE. Cardiologist involvement was } \\
\text { voluntary, and most chose to participate. There was no } \\
\text { advertising of the program. There was prompt feedback to } \\
\text { the referring physician. } \\
\text { Implementation fidelity: NA }\end{array}$ \\
\hline $\begin{array}{l}\text { Macleod et al. } \\
(2009),{ }^{10} \\
\text { Canada }\end{array}$ & $\begin{array}{l}\text { Simple pre-post with } \\
\text { non-equivalent } \\
\text { groups, time series }\end{array}$ & NA & $\begin{array}{l}\text { Single payer, } \\
\text { surgery: hip and } \\
\text { knee }\end{array}$ & $\begin{array}{c}\text { Central intake, } \\
\text { optional }\end{array}$ & $\begin{array}{l}\text { The HKRP was a centralized intake model in which } \\
\text { referrals were registered and triaged by an advanced } \\
\text { practice physiotherapist. Six hospitals within the TC LHIN } \\
\text { implemented the HKRP. There was a single wait list, with } \\
\text { technology to support referral management. } \\
\text { Implementation fidelity: TC LHIN was accountable for the } \\
\text { HKRP. The organization monitored wait lists under the } \\
\text { Wait Times Strategy and worked collaboratively with } \\
\text { hospitals to improve TC LHIN wait list management } \\
\text { processes. }\end{array}$ \\
\hline $\begin{array}{l}\text { Van den } \\
\text { Heuvel et al. } \\
\text { (2012), }{ }^{16} \\
\text { Canada }\end{array}$ & Cross-sectional & 94 patients & $\begin{array}{l}\text { Single payer, } \\
\text { surgery: hernia } \\
\text { clinic }\end{array}$ & $\begin{array}{l}\text { Common } \\
\text { waiting list, } \\
\text { optional }\end{array}$ & $\begin{array}{l}\text { Patients were put on a common waiting list to await next } \\
\text { available physician. Clinic was run by } 4 \text { surgeons, as well } \\
\text { as fellows, residents and students. All administrative data } \\
\text { were input into a single database. Triage was performed } \\
\text { by surgeon. } \\
\text { Implementation fidelity: Letter was sent to FPs informing } \\
\text { them of the new initiative. Patients received letter with } \\
\text { date and time of appointment, along with information } \\
\text { about the hernia clinic, health questionnaire and QoL } \\
\text { questionnaire. }\end{array}$ \\
\hline $\begin{array}{l}\text { Schachter et } \\
\text { al. (2013), }{ }^{7} \\
\text { Canada }\end{array}$ & $\begin{array}{l}\text { Prospective, pre-post } \\
\text { with non-equivalent } \\
\text { groups, time series }\end{array}$ & $\begin{array}{c}920 \\
\text { patients }\end{array}$ & $\begin{array}{l}\text { Single payer, } \\
\text { nephrology }\end{array}$ & $\begin{array}{c}\text { Central triage, } \\
\text { optional }\end{array}$ & $\begin{array}{l}\text { A physician-led provincial change strategy was } \\
\text { implemented. Wait time issue was brought up in a } \\
\text { preliminary survey at a BC nephrology conference in } \\
2009 \text {. In addition, through a modified Delphi process, } \\
\text { in-person meetings and surveys, wait time targets were } \\
\text { established. Time targets took into account comorbidities, } \\
\text { eGFR, BP and albuminuria. A priority score from } 1 \text { to } 4 \\
\text { was assigned for referred conditions. Finally, the } \\
\text { benchmark targets were approved by BC nephrologists at } \\
\text { the BCPRA Medical Advisory Committee meeting and } \\
\text { were then disseminated to all nephrologists in BC. } \\
\text { A hard-copy reference sheet was provided for use during } \\
\text { triage of new patients. } \\
\text { Implementation fidelity: NA }\end{array}$ \\
\hline $\begin{array}{l}\text { Clark (2015), }{ }^{11} \\
\text { Canada }\end{array}$ & $\begin{array}{l}\text { Simple pre-post with } \\
\text { non-equivalent } \\
\text { groups, time series }\end{array}$ & NA & $\begin{array}{l}\text { Single payer, } \\
\text { chronic pain }\end{array}$ & $\begin{array}{c}\text { Central intake, } \\
\text { optional }\end{array}$ & $\begin{array}{l}\text { All referrals were triaged by a nurse and administrative } \\
\text { staff. Wait lists at } 3 \text { different sites were centralized, } \\
\text { duplicates were identified, and a single wait list was } \\
\text { formed. } \\
\text { Implementation fidelity: NA }\end{array}$ \\
\hline
\end{tabular}


Table 1 (part 2 of 2): Characteristics of included studies

\begin{tabular}{|c|c|c|c|c|c|}
\hline $\begin{array}{l}\text { Reference } \\
\text { (year) and } \\
\text { country }\end{array}$ & Study design & $\begin{array}{l}\text { Sample } \\
\text { size }\end{array}$ & $\begin{array}{l}\text { Health system } \\
\text { and specialty } \\
\text { setting }\end{array}$ & $\begin{array}{c}\text { Characteristics } \\
\text { of SEM }\end{array}$ & Implementation process and fidelity \\
\hline $\begin{array}{l}\text { Hazlewood et } \\
\text { al. (2016), }{ }^{6} \\
\text { Canada }\end{array}$ & $\begin{array}{l}\text { Simple pre-post with } \\
\text { nonequivalent } \\
\text { groups, time series }\end{array}$ & $\begin{array}{l}8414 \\
\text { referrals }\end{array}$ & $\begin{array}{l}\text { Single payer, } \\
\text { rheumatology }\end{array}$ & $\begin{array}{c}\text { Central intake, } \\
\text { optional }\end{array}$ & $\begin{array}{l}\text { CReATe Rheum was a centralized referral system. } \\
\text { Referrals were sent via a single fax number. A } \\
\text { standardized referral form was given to the RP, but the } \\
\text { form was not enforced if all required information was } \\
\text { given in the referral letter. A nurse with > } 15 \text { yr experience } \\
\text { and } 2 \text { clerical support persons processed referrals to } \\
\text { physicians. Any concerns with referrals were directed to } \\
2 \text { senior rheumatologists. A multiuser database was } \\
\text { developed to track referrals, and missing information was } \\
\text { obtained by sending a standardized form to the RP. } \\
\text { Evaluation was conducted to determine impact over the } \\
\text { short term ( } 2 \text { yr) and the long term (until } 2013 \text { ). } \\
\text { Implementation fidelity: The } 2 \text { senior rheumatologists } \\
\text { were involved in providing training to other } \\
\text { rheumatologists to ensure easy transition to new system. }\end{array}$ \\
\hline $\begin{array}{l}\text { Wittmeier et al. } \\
(2016),^{18} \\
\text { Canada }\end{array}$ & $\begin{array}{l}\text { Simple pre-post with } \\
\text { nonequivalent } \\
\text { groups, time series }\end{array}$ & $\begin{array}{c}1399 \\
\text { patients }\end{array}$ & $\begin{array}{l}\text { Single payer, } \\
\text { physiotherapy }\end{array}$ & $\begin{array}{c}\text { Central intake, } \\
\text { mandatory }\end{array}$ & $\begin{array}{l}\text { A central intake system was implemented by the Child } \\
\text { Health Physiotherapy team at the Health Sciences Centre } \\
\text { in Winnipeg for children with complex needs. } \\
\text { Implementation fidelity: NA }\end{array}$ \\
\hline $\begin{array}{l}\text { Goodsall et al. } \\
(2017),^{19} \\
\text { Australia }\end{array}$ & $\begin{array}{l}\text { Simple pre-post with } \\
\text { nonequivalent } \\
\text { groups, time series }\end{array}$ & $\begin{array}{c}1118 \\
\text { referrals }\end{array}$ & $\begin{array}{c}\text { Two-tier, } \\
\text { gastroenterology }\end{array}$ & $\begin{array}{l}\text { Single point of } \\
\text { entry, } \\
\text { mandatory }\end{array}$ & $\begin{array}{l}\text { A pooled waiting list and centralized intake and triage } \\
\text { with a "week on" roster for staff specialists was } \\
\text { implemented. Intake and triage were categorized as } \\
\text { "urgent" or "routine." Patients were seen by the next } \\
\text { available provider, and a rapid access clinic was } \\
\text { established for urgent cases. } \\
\text { Implementation fidelity: NA }\end{array}$ \\
\hline \multicolumn{6}{|c|}{ 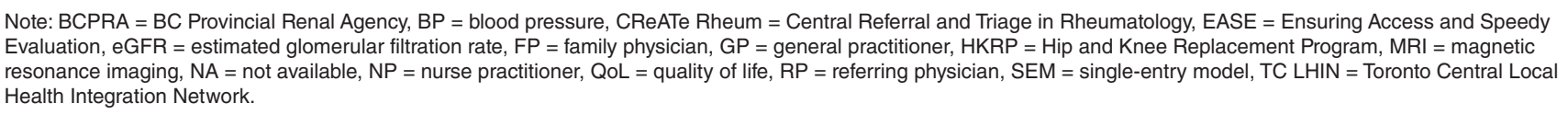 } \\
\hline
\end{tabular}

\section{Effects of single-entry model on wait time and volume}

Table 3 summarizes the main outcomes of the included studies. All of the studies reported a reduction in WT1 (Figure 2), and this reduction was statistically significant in 6 of the studies.,14,15,17-19 The improvement in WT1 after implementation was highest in the study by $\mathrm{Clark}^{11}$ and lowest in the study by Wittmeier and colleagues ${ }^{18}(274 \mathrm{v}$. $5.5 \mathrm{~d}$ ). When categorized by specialty, the average absolute reduction was highest in the "other" category and lowest for urgent referrals to internal medicine at (140 v. 12 days; Figure 3). However, the average percent reduction in WT1 across specialties was highest for surgery $(57 \%$ relative reduction) and for urgent referrals to internal medicine (40\% relative reduction) (Figure 4). Moderate-level and routine referrals to internal medicine were associated with lower percent reductions in WT1 $36 \%$ and $17 \%$ relative reductions, respectively).

On univariable linear regression, pre-implementation wait times were associated with an absolute reduction in WT1 $\left(R^{2}=0.5978, p=0.002\right)$ (Figure 5). For every 1 -day increase in the pre-implementation wait time, it is expected that the absolute reduction in WT1 will increase by 0.5 days (Figure 5). On a relative basis, there was a $0.065 \%$ relative reduction in WT1 for every 1-day increase in the pre-implementation wait time, although a significant amount of variability was not captured by the linear model $\left(R^{2}=0.062\right)$.
Of the 3 studies that reported on mandatory implementation of a single-entry model, the range of WT1 improvement was 5.5 to 47 days. ${ }^{14,18,19}$ The other 7 studies, which allowed for optional involvement, had a range of improvement in WT1 from 6 days to 9 months. ${ }^{6} 10-12,15-17$

Patient volume was measured in 4 of the studies, ${ }^{14,15,17,18}$ with variable results. One study found no change in referral volume for rheumatology and hematology practices after implementation of the single-entry model, but did find increased referral volumes for endocrinology, gastroenterology and general internal medicine practices..$^{14}$ In the cardiology study, patient volume increased by $50 \%$ in the first year after implementation and by another $19 \%$ in the second year. ${ }^{15}$ In the study by Schacter and colleagues, ${ }^{17}$ there was a $22 \%$ reduction in referral volume in nephrology. Wittmeier and colleagues $^{18}$ found that the referral volume for physiotherapy stayed the same after implementation of a single-entry model for a group of children with neurodevelopmental conditions, but increased for pediatric orthopedic clinics.

\section{Patient and physician satisfaction}

Appendix 3 (available at www.cmajopen.ca/content/9/2/E413/ suppl/DC1) summarizes patient and physician satisfaction in the included studies. Three of the studies described patient satisfaction after implementation of a single-entry model,,$^{10,16,18}$ although only 1 study provided data from patients referred before and after implementation. ${ }^{18}$ 
Table 2: Assessment of risk of bias, based on the Risk of Bias in Nonrandomized Studies of Interventions tool ${ }^{13}$

\begin{tabular}{|c|c|c|c|c|c|c|c|c|c|c|}
\hline \multirow[b]{2}{*}{ Article } & \multicolumn{8}{|c|}{ Type of bias } & \multirow[b]{2}{*}{$\begin{array}{c}\text { Conflict of } \\
\text { interest }\end{array}$} & \multirow[b]{2}{*}{ Funding* } \\
\hline & Confounding & $\begin{array}{l}\text { Selection of } \\
\text { participants }\end{array}$ & $\begin{array}{l}\text { Classification } \\
\text { of interventions }\end{array}$ & $\begin{array}{l}\text { Deviations from } \\
\text { interventions }\end{array}$ & $\begin{array}{l}\text { Missing } \\
\text { data }\end{array}$ & $\begin{array}{l}\text { Measurement of } \\
\text { outcomes }\end{array}$ & $\begin{array}{l}\text { Selection of } \\
\text { results }\end{array}$ & Overall & & \\
\hline $\begin{array}{l}\text { Leach et } \\
\text { al. }(2004)^{12}\end{array}$ & Serious & Moderate & Low & Low & Low & Moderate & Low & Serious & Unclear & Unclear \\
\hline $\begin{array}{l}\text { Bichel et } \\
\text { al. }(2009)^{14}\end{array}$ & Serious & Low & Low & Moderate & Moderate & Low & Low & Serious & Unclear & Low \\
\hline $\begin{array}{l}\text { Bungard et } \\
\text { al. }(2009)^{15}\end{array}$ & Serious & Low & Low & Moderate & Low & Low & Low & Serious & Unclear & Low \\
\hline $\begin{array}{l}\text { Macleod et } \\
\text { al. }(2009)^{10}\end{array}$ & Serious & Critical & Low & Low & Moderate & Low & Low & Critical & Unclear & Unclear \\
\hline $\begin{array}{l}\text { Van den } \\
\text { Heuvel et } \\
\text { al. }(2012)^{16}\end{array}$ & Critical & Low & Low & Moderate & Moderate & Moderate & Moderate & Critical & High & Unclear \\
\hline $\begin{array}{l}\text { Schachter } \\
\text { et al. } \\
(2013)^{17}\end{array}$ & Serious & Moderate & Low & Moderate & Moderate & Low & Low & Serious & Unclear & Low \\
\hline $\begin{array}{l}\text { Clark } \\
(2015)^{11} \dagger\end{array}$ & Serious & Low & Low & Moderate & Moderate & Low & Low & Serious & Unclear & Unclear \\
\hline $\begin{array}{l}\text { Hazlewood } \\
\text { et al. } \\
(2016)^{6}\end{array}$ & Serious & Low & Low & Moderate & Serious & Low & Low & Serious & Unclear & Low \\
\hline $\begin{array}{l}\text { Wittmeier } \\
\text { et al. } \\
(2016)^{18}\end{array}$ & Serious & Low & Low & Moderate & Moderate & Low & Moderate & Serious & Low & Low \\
\hline $\begin{array}{l}\text { Goodsall } \\
\text { et al. } \\
(2017)^{19}\end{array}$ & Serious & Moderate & Low & Moderate & Moderate & Low & Low & Serious & Unclear & Unclear \\
\hline
\end{tabular}

All of the studies reported positive patient satisfaction or improvement in satisfaction with single-entry models. Van den Heuvel and colleagues ${ }^{16}$ found that patients who had the same surgeon for assessment and surgery (group 1) rated the importance of having the same surgeon higher than the group that did not have the same surgeon for surgery and assessment (group 2) (98.4\% v. 48.3\%). Regardless of whether patients had the same surgeon for both assessment and surgery, patients' confidence in the surgeon was high in both groups (group 1, 100\%; group 2, 86.2\%; $p=0.009$ ). As well, both groups felt that service was faster and better with a common waiting list. ${ }^{16}$ Wittmeier and colleagues ${ }^{18}$ found that patient satisfaction was high both before and after implementation of a central intake system $(96.6 \%$ and $98 \%$, respectively). As well, caregivers reported that implementation of a single-entry model provided more transparency for accessing services, more accurate information on wait times, better availability, improved communication and a reduction in service duplication. ${ }^{18}$

One study provided data on provider satisfaction after implementation of a single-entry model. ${ }^{6}$ After implementation of a central intake model, providers deemed referrals as having higher quality (before implementation, one-third of rheumatologists rated referrals as being of poor quality; after implementation, rheumatologists rated $19 \%$ of referrals as being of poor quality) and more complete (before implementation, $75 \%$ were not satisfied with the completeness of referral; after implementation, $68 \%$ rated the completeness of referral as moderate and $19 \%$ rated it as high). ${ }^{18}$

\section{Interpretation}

In this systematic review, we found that implementation of a single-entry model was consistently associated with a decrease in the wait time to initial outpatient visit to a specialist (WT1). The average percent reduction in WT1 was significant for surgery, for urgent referrals to an internal medicine specialist and for children with complex needs, which suggests that a centralized intake system may be more helpful for higher-priority referrals. Additionally, the evidence suggests that single-entry models were associated with greater absolute reductions in WT1 when implemented in situations with longer initial wait times. These findings should be considered hypothesis-generating, given the variability in implementation and reporting among the studies, as well as the risk of bias noted in each study.

In their 2017 systematic review, Damani and colleagues ${ }^{5}$ showed that single-entry models improved access to elective surgical procedures. For such surgical services, they found that a single-entry model resulted in a decrease in patients' 


\begin{tabular}{|c|c|c|c|c|c|c|c|}
\hline \multirow[b]{2}{*}{ Reference } & \multicolumn{2}{|c|}{$\mathrm{WT} 1$, mean $\pm \mathrm{SD}^{*}$} & \multicolumn{2}{|c|}{ Reduction, mean $\pm \mathrm{SD}^{*}$} & \multirow[b]{2}{*}{ Patient volume } & \multicolumn{2}{|c|}{ WT1 for control group } \\
\hline & Before SEM & After SEM & Absolute & Relative, \% & & Before SEM & After SEM \\
\hline $\begin{array}{l}\text { Leach et al. } \\
(2004)^{12}\end{array}$ & $\begin{array}{l}\text { No. of patients waiting } \\
>26 \text { wk: } 85 \\
\text { No. of patients waiting } \\
\text { 13-26 wk: } 90\end{array}$ & $\begin{array}{l}\text { No. of patients } \\
\text { waiting > } 26 \mathrm{wk}: 0 \\
\text { No. of patients } \\
\text { waiting } 13-26 \mathrm{wk}: 15\end{array}$ & $\begin{array}{l}\text { No. of patients } \\
\text { waiting }>26 \text { wk: } \\
85 \\
\text { No. of patients } \\
\text { waiting 13-26 wk: } \\
75\end{array}$ & $\begin{array}{l}\% \text { of patients } \\
\text { waiting }>26 \text { wk: } \\
100 \\
\% \text { of patients } \\
\text { waiting } 13-26 \text { wk: } \\
83.3\end{array}$ & NA & NA & NA \\
\hline $\begin{array}{l}\text { Bichel et al. } \\
(2009)^{14}\end{array}$ & $\begin{array}{l}\text { Urgent: } 29 \pm 46 \mathrm{~d} \\
\text { Moderate-level: } \\
110 \pm 57 \mathrm{~d} \\
\text { Routine: } 155 \pm 88 \mathrm{~d}\end{array}$ & $\begin{array}{l}\text { Urgent: } 17 \pm 14 \mathrm{~d} \\
(p<0.05) \\
\text { Moderate-level: } \\
63 \pm 42 \mathrm{~d} \\
(p<0.00005) \\
\text { Routine: } 108 \pm 37 \mathrm{~d} \\
\text { (statistical test not } \\
\text { performed) }\end{array}$ & $\begin{array}{l}\text { Urgent: } 12 \pm 48 \mathrm{~d} \\
\text { Moderate-level: } \\
47 \pm 71 \mathrm{~d} \\
\text { Routine: } \\
47 \pm 95 \mathrm{~d}\end{array}$ & $\begin{array}{l}\text { Urgent: mean } 41.4 \\
\text { Moderate-level: } \\
\text { mean } 42.7 \\
\text { Routine: } \\
\text { mean } 30.3\end{array}$ & $\begin{array}{l}\text { Increases in referral } \\
\text { volume: } 75 \% \text { for } \\
\text { endocrinology, } 50 \% \\
\text { for gastroenterology, } \\
26 \% \text { for general } \\
\text { internal medicine; } \\
\text { no change in referral } \\
\text { volume for } \\
\text { rheumatology and } \\
\text { hematology }\end{array}$ & NA & NA \\
\hline $\begin{array}{l}\text { Bungard et } \\
\text { al. }(2009)^{15}\end{array}$ & $71 \pm 45 d$ & $\begin{array}{c}33 \pm 19 d \\
(p<0.001)\end{array}$ & $38 \pm 49 d$ & 53.5 & $\begin{array}{l}\text { Increase by about } \\
50 \% \text { from } 2004 \text { to } \\
2005 \text { and by } 19 \% \\
\text { from } 2005 \text { to } 2006\end{array}$ & NA & NA \\
\hline $\begin{array}{l}\text { Macleod et } \\
\text { al. }(2009)^{10}\end{array}$ & $\begin{array}{l}\text { Knee: } 203 \text { d } \\
\text { Hip: } 162 \text { d }\end{array}$ & $\begin{array}{l}\text { Knee: } 115 d \\
\text { Hip: } 98 \mathrm{~d}\end{array}$ & $\begin{array}{c}\text { Knee: } 88 \text { d } \\
\text { Hip: } 64 \text { d }\end{array}$ & $\begin{array}{c}\text { Knee: } 43.3 \\
\text { Hip: } 39.5\end{array}$ & NA & NA & NA \\
\hline $\begin{array}{l}\text { Van den } \\
\text { Heuvel et al. } \\
(2012)^{16}\end{array}$ & $208 \pm 139 d$ & $59 \pm 70 d$ & $149 \pm 156 d$ & 71.6 & NA & NA & NA \\
\hline $\begin{array}{l}\text { Schacter et } \\
\text { al. }(2013)^{17}\end{array}$ & $98 \pm 84 d$ & $64 \pm 73 d$ & $34 \pm 111 d$ & 34.7 & NA & NA & NA \\
\hline $\begin{array}{l}\text { Clark } \\
(2015)^{11}\end{array}$ & About 24 to $>48 \mathrm{mo}$ & $\begin{array}{l}\text { 9-mo overall } \\
\text { reduction }\end{array}$ & $274 d$ & NA & NA & NA & NA \\
\hline $\begin{array}{l}\text { Hazlewood } \\
\text { et al. }(2016)^{6}\end{array}$ & $\begin{array}{l}\text { Routine: } 155 \pm 88 \mathrm{~d} \\
\text { Moderate-level: } \\
110 \pm 57 \mathrm{~d} \\
\text { Urgent: } 29 \pm 46 \mathrm{~d}\end{array}$ & $\begin{array}{l}\text { Routine: } 149 \pm 65 \mathrm{~d} \\
(p=0.11) \\
\text { Moderate-level: } 78 \pm \\
56 \mathrm{~d}(p<0.001) \\
\text { Urgent: } 18 \pm 23 \mathrm{~d} \\
(p=0.01)\end{array}$ & $\begin{array}{l}\text { Routine: } \\
6 \pm 109 \mathrm{~d} \\
\text { Moderate-level: } \\
32 \pm 80 \mathrm{~d} \\
\text { Urgent: } \\
11 \pm 51 \mathrm{~d}\end{array}$ & $\begin{array}{l}\text { Routine: } 3.87 \\
\text { Moderate-level: } \\
29.1 \\
\text { Urgent: } 37.9\end{array}$ & NA & NA & NA \\
\hline $\begin{array}{l}\text { Wittmeier et } \\
\text { al. }(2016)^{18}\end{array}$ & $\begin{array}{l}\text { Children with } \\
\text { complex needs } \\
\text { (neurodevelopmental } \\
\text { conditions): } \\
29.8 \pm 17.9 \text { d }\end{array}$ & $\begin{array}{l}\text { Children with } \\
\text { complex needs: } \\
24.3 \pm 17.0 \mathrm{~d} \\
(p<0.0001)\end{array}$ & $5.5 \pm 25 d$ & 18.5 & $\begin{array}{l}\text { Complex needs: } \\
\text { same referral volume } \\
\text { Comparison groups: } \\
\text { increased referral } \\
\text { volume }\end{array}$ & $\begin{array}{l}\text { Comparison } \\
\text { group } \\
\text { (orthopedic } \\
\text { conditions): } \\
20.4 \pm 14.3 \mathrm{~d}\end{array}$ & $\begin{array}{l}\text { Comparison } \\
\text { group: } \\
22.1 \pm 13.1 \mathrm{~d} \\
(p<0.0001)\end{array}$ \\
\hline $\begin{array}{l}\text { Goodsall et } \\
\text { al. }(2017)^{19}\end{array}$ & $78 d$ & $\begin{array}{c}58 \mathrm{~d} \\
(p<0.01)\end{array}$ & $20 d$ & 25.6 & NA & NA & NA \\
\hline
\end{tabular}

waiting times, an increase in the proportion of patients meeting wait time benchmarks and a decrease in the length of waiting lists. ${ }^{5}$ Our current review builds upon those results, indicating the potential benefit of single-entry models beyond surgical care and synthesizing the evidence related to implementation strategy, referral volumes, and both patient and provider satisfaction.

The range in effects observed for referral volume could be due to differences in the complexity of referrals, the nature of the field of practice, local referral patterns, education about appropriate referrals and the referring specialists' comfort, ability and satisfaction with the new model. ${ }^{14,15,17,18}$ When reported, patient and provider satisfaction improved after implementation of a single-entry model. ${ }^{6,10,16,18}$ One study reported that the quality of referrals improved after implementation; however, it is not clear if this finding was due to use of a standardized referral form that was given to the referring physicians during the post-implementation period, or if it was due to the single-entry model. ${ }^{6}$ By comparison, Damani and colleagues ${ }^{5}$ found that single-entry models may leave specialists and referring physicians with a reduced sense of personal ownership over the referral system.

Another model, termed the specific timely appointment for triage (STAT) model, has been proposed and investigated for reducing wait times to appointments. ${ }^{27}$ This model is based on assumptions about the referral volume of a practice. STAT slots are protected in clinicians' schedules, according to patient demand. More specifically, each physician creates a 


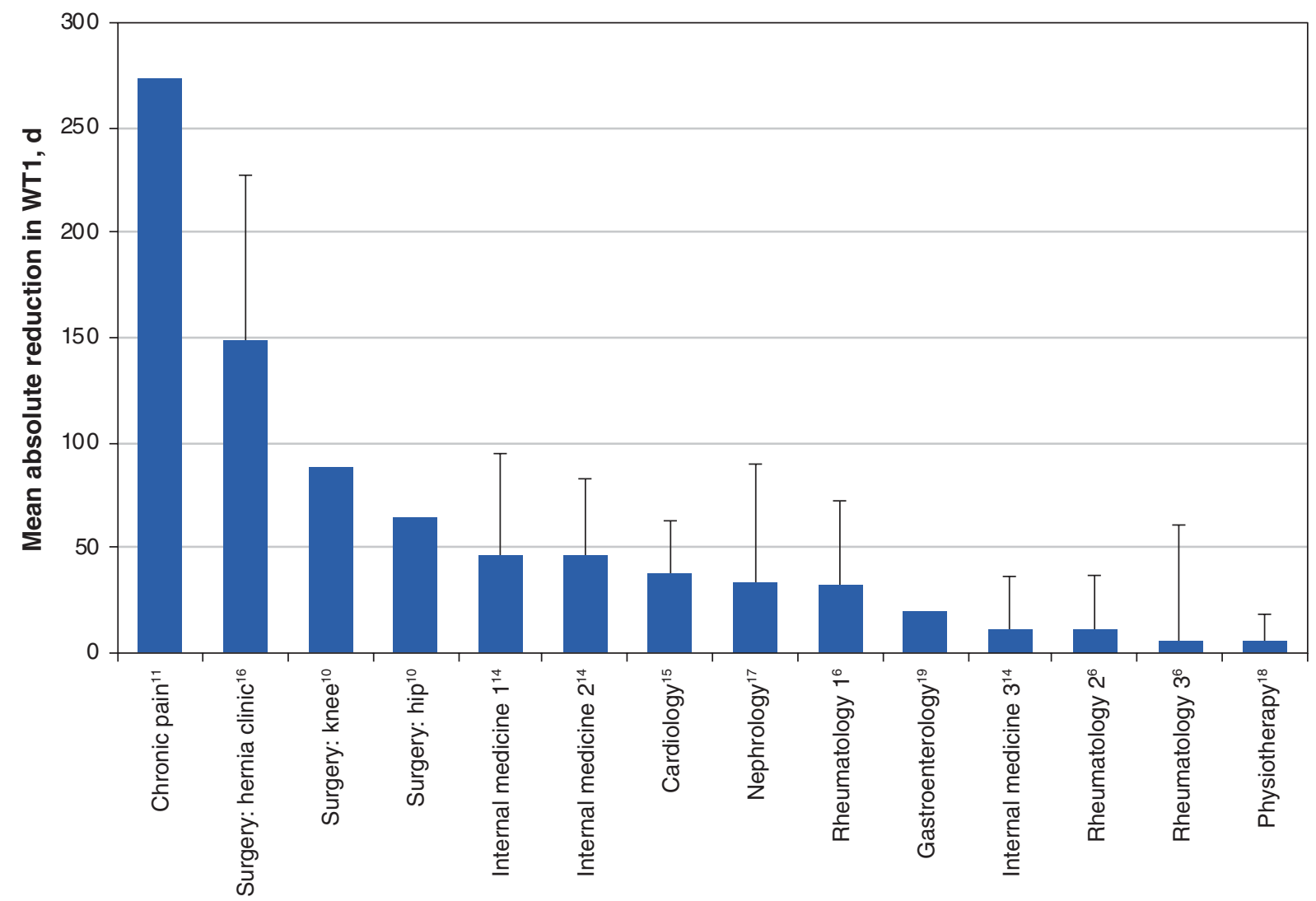

Study

Figure 2: Absolute reduction in wait time 1 (WT1) across the included studies. For purposes of this figure, the total number of studies was 9 ; the study by Leach and colleagues ${ }^{12}$ was omitted because the published report lacked continuous data. Error bars represent the standard deviation, where it was reported in the included studies. Note: For internal medicine, 1 = routine, $2=$ moderate, $3=$ urgent; for rheumatology, $1=$ moderate, 2 = urgent, 3 = routine.

certain number of STAT time slots depending on the anticipated demand for referrals. As a result, new patients are booked into the STAT slots and are potentially seen faster. ${ }^{27}$ E-consultations represent another complementary option that makes specialist knowledge and advice more accessible to primary care. ${ }^{28,29}$

\section{Limitations}

The limitations of the available data that we identified through this review deserve consideration. The included studies came from only 3 countries (Canada, Australia and England), which limits the external validity of the findings. Only 3 studies reported on patient satisfaction, and only 1 study reported on provider satisfaction.

There was also considerable variability with respect to the reporting of results in the individual studies. For instance, for 3 of the included studies, ${ }^{10,11,19}$ no measure of variability was available (as shown in Figure 2), nor was an associated sample size reported. As such, we could not calculate weighted averages, because either the sample sizes were unknown or the sample sizes for specific categories (urgent, moderate-level or routine referrals) were not specified.
For certain studies, it was not possible to extract the associated uncertainty of the effect size observed. Furthermore, the sustainability of single-entry models (i.e., the ability of the models to persist over time) was not adequately assessed in any study. Unsustainable models can lead to poor quality of care, financial consequences and worsening of patient outcomes. ${ }^{30}$ Similarly, few studies reported on implementation fidelity, and for those that did, efforts to ensure fidelity (or adaptation) were not adequately described. ${ }^{6,10,16}$ Likewise, the only indication of cost-effectiveness in our review came from the study by Leach and colleagues, ${ }^{12}$ who mentioned that their single-entry system was cost-neutral.

There may have been natural variations in WT1 in the pre-implementation period. An example of this occurred in the study by Macleod and colleagues, ${ }^{10}$ where a decrease in WT1 (from 162 to $127 \mathrm{~d}$ for hip replacement and from 203 to $164 \mathrm{~d}$ for knee replacement) was seen from the 2 -month period August-September 2005 to the corresponding 2 -month period August-September 2006, both of which were in the pre-implementation period. We chose to analyze the earliest pre-implementation and latest post-implementation values, to avoid the collection of peri-implementation artifactual 


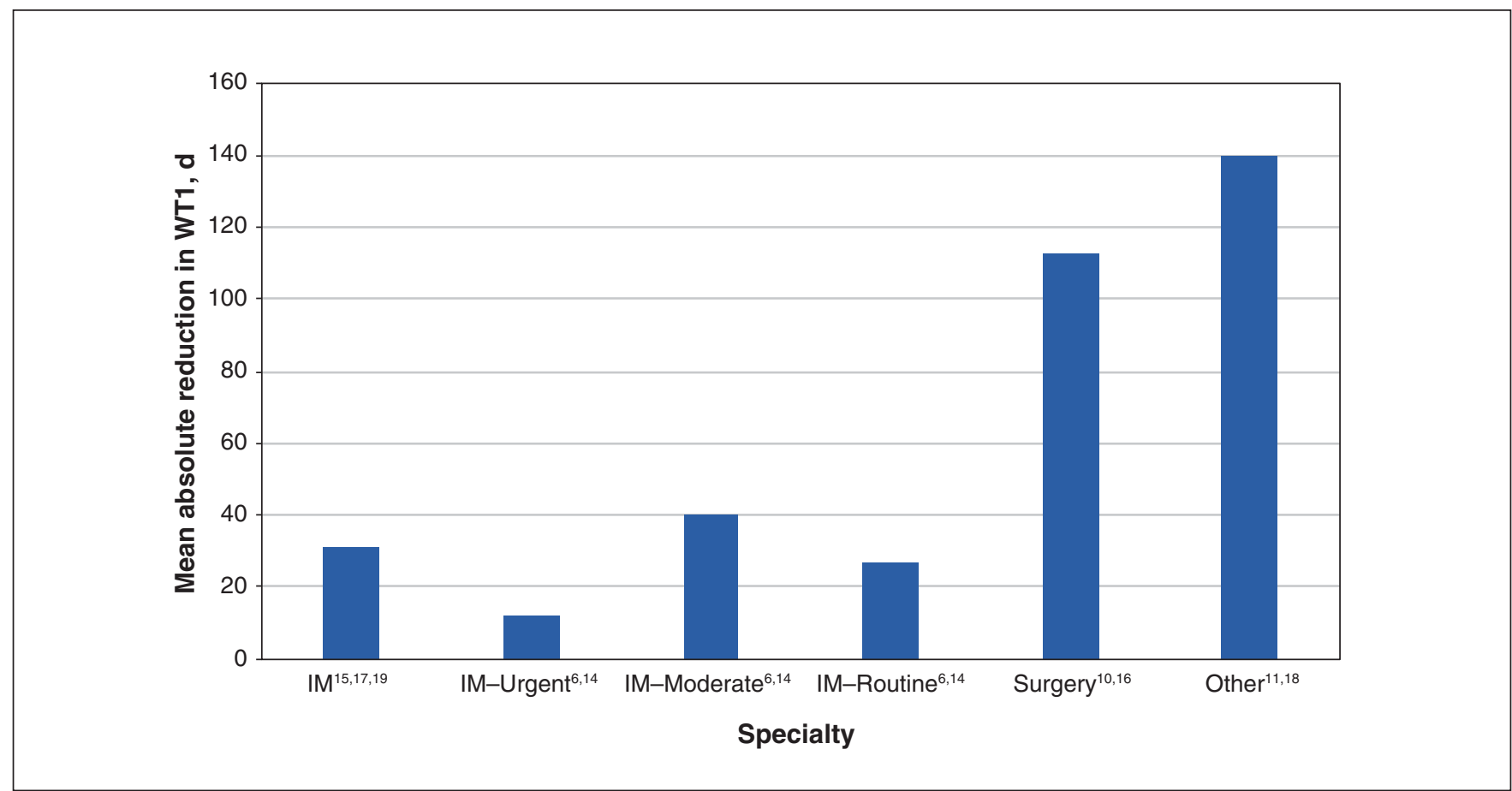

Figure 3: Mean absolute reduction in wait time 1 (WT1) across specialties. For purposes of this figure, the total number of studies was 9 ; the study by Leach and colleagues ${ }^{12}$ was omitted because the published report lacked continuous data. The estimates of absolute reduction stratified by specialty were derived from multiple studies. For internal medicine (IM), the first data point represents a mean of all levels of referral from multiple studies, whereas other IM data points represent specific values for different levels of referral, as reported in the cited studies. Note: "other" = chronic pain and physiotherapy.

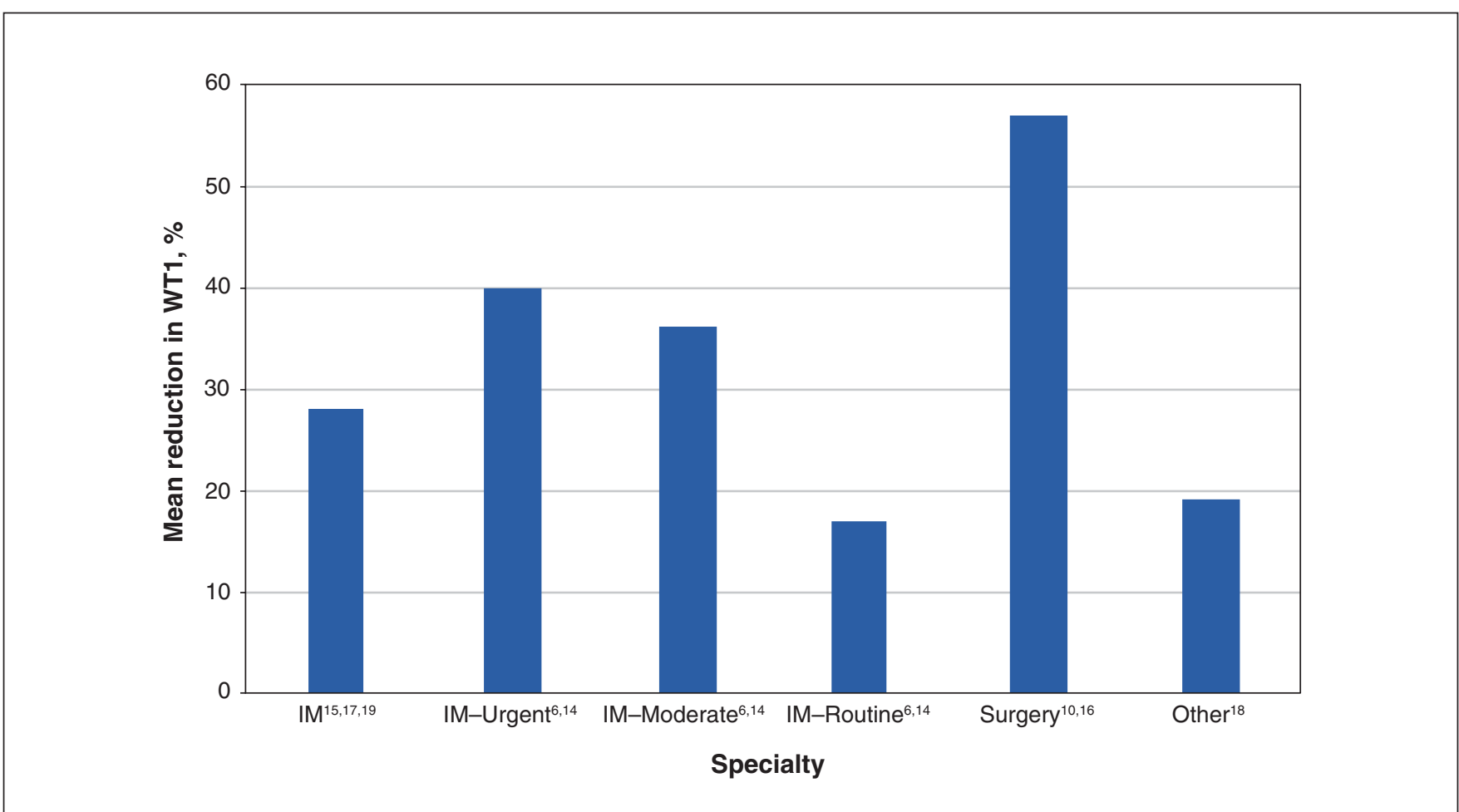

Figure 4: Mean percent reduction in wait time 1 (WT1) across specialties. For purposes of this figure, the total number of studies was 8; the studies by Clark ${ }^{11}$ and Leach and colleagues ${ }^{12}$ were omitted because percent reduction in WT1 could not be calculated from the published data. For internal medicine (IM), the first data point represents a mean of all levels of referral from multiple studies, whereas other IM data points represent specific values for different levels of referral, as reported in the cited studies. Note: "other" = physiotherapy. 


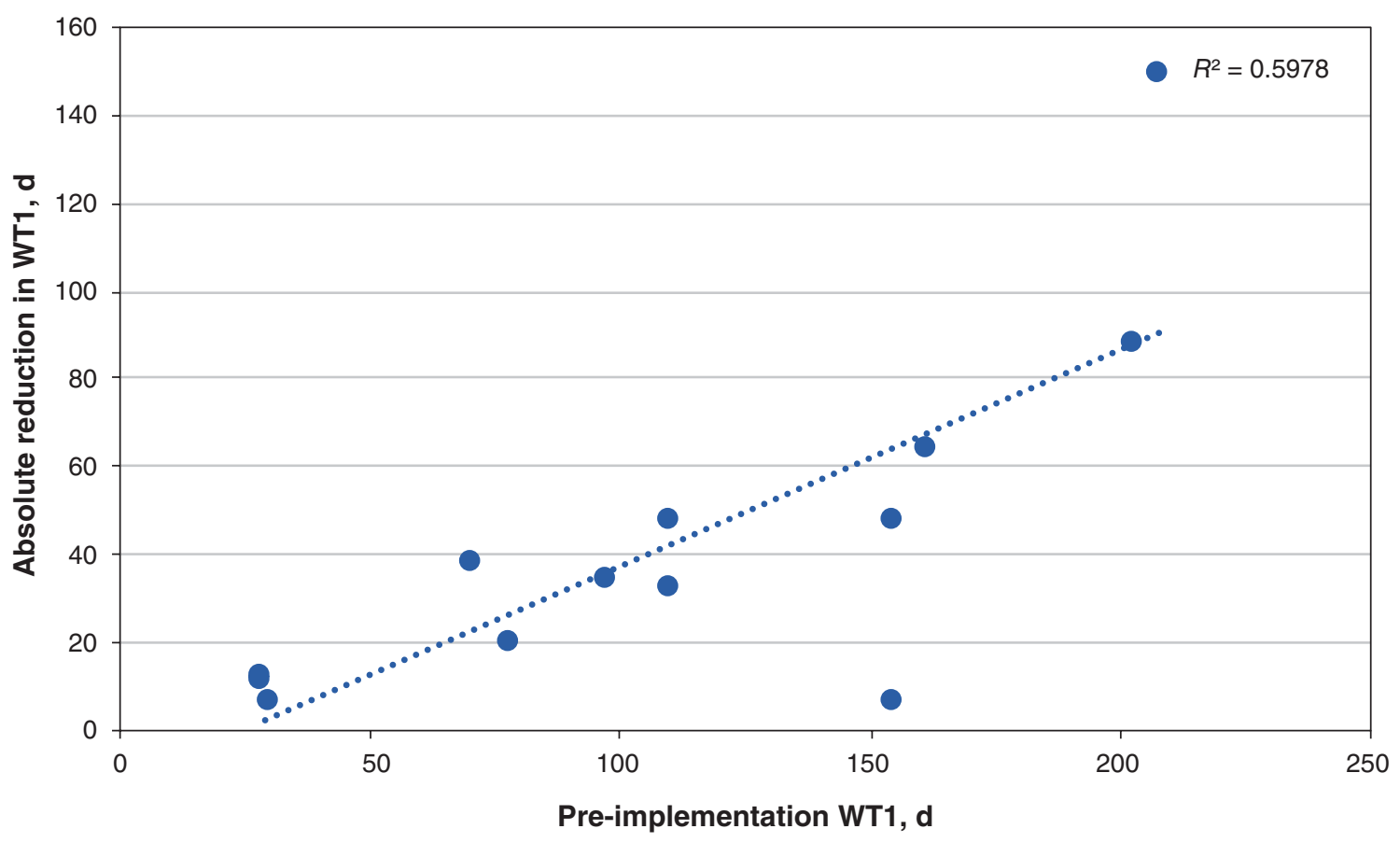

Figure 5: Relation between absolute reduction in wait time 1 (WT1) and pre-implementation WT1. For purposes of this figure, the total number of studies was 8; the studies by Clark ${ }^{11}$ and Leach and colleagues ${ }^{12}$ were omitted because continuous data were not available.

data, and these natural variations in baseline WT1 might have affected the observed results.

We identified a serious or critical risk of bias across all included studies. Specifically, there was high risk of confounding in all studies. Eight articles used a simple before-and-after comparative study design, which did not allow us to determine whether differences between the 2 periods were due to any variable other than implementation of the single-entry model.

Means and standard deviations for the reduction in WT1 after implementation of the single-entry model were computed at the level of the cohort. Ecological fallacy contends that these estimates may not necessarily hold true at the level of the individual patient.

Because of heterogeneity in study design, outcome measures and populations, we did not conduct a meta-analysis. Publication bias was also a possibility in this review, but this source of bias is difficult to assess statistically because of limited reporting of standard errors within the included studies. In a related manner, we included studies whether or not they had been peerreviewed, because of the paucity of peer-reviewed literature in this setting. We did not consider any grey literature.

Given the substantial risk of confounding that exists secondary to patient-, provider- and system-level factors, wait times before and after implementation of a single-entry model should be compared in studies that control for confounding factors, with randomization, matching, restriction, stratification or multivariable regression, depending on context. ${ }^{31}$

\section{Conclusion}

This review showed that single-entry models for referral to specialist physicians and allied health professionals have the potential to decrease WT1, but there remains uncertainty about their efficacy, cost-effectiveness and sustainability. Furthermore, it remains uncertain whether these models can be applied to all specialties and across diverse settings. As well, single-entry models may affect not only average wait times across study cohorts, but also the variation in wait times, which should be the focus of further investigations. It is unknown whether improvements in WT1 through the implementation of a single-entry model significantly affects health outcomes. Studies evaluating singleentry models should feature methodologic or statistical methods to control bias.

\section{References}

1. Siciliani L, Borowitz M, Moran V, editors. Waiting time policies in the health sector: What works? Paris: OECD Publishing; 2013. Available: www.oecd-ilibrary.org/ social-issues-migration-health/waiting-times-for-elective-surgery-what-works 9789264179080-en (accessed 2019 June 29).

2. Barua B. When compared to similar countries, Canada's health-care wait times are the worst. Vancouver: Fraser Institute; 2017. Available: www.fraserinstitute.org/ article/when-compared-to-similar-countries-canadas-health-care-wait-times -are-the-worst (accessed 2019 July 2).

3. Barua B, Jacques D. Waiting your turn: wait times for bealth care in Canada, 2018 report. Vancouver: Fraser Institute 2018. Available: www.fraserinstitute.org/ sites/default/files/waiting-your-turn-2018.pdf (accessed 2019 July 2).

4. Novak K, Van Zanten V, Pendharkar SR. Improving access in gastroenterology: the single point of entry model for referrals. Can 7 Gastroenterol 2013;27:633-5. 
5. Damani Z, Conner-Spady B, Nash T, et al. What is the influence of singleentry models on access to elective surgical procedures? A systematic review. BM7 Open 2017;7:e012225.

6. Hazlewood GS, Barr SG, Lopatina E, et al. Improving appropriate access to care with central referral and triage in rheumatology. Arthritis Care Res (Hoboken) 2016;68:1547-53

7. Moher D, Liberati A, Tetzlaff J, et al.; PRISMA Group. Preferred reporting items for systematic reviews and meta-analyses: the PRISMA statement. PLoS Med 2009;6:e1000097.

8. Where: global reach. Paris: Organisation for Economic Co-operation and Development. Available: www.oecd.org/about/members-and-partners/ (accessed 2020 Apr. 2)

9. Pinnock H, Sheikh A. Standards for reporting implementation studies (StaRI): enhancing reporting to improve care. NP7 Prim Care Respir Med 2017;27:42.

10. Macleod AM, Gollish J, Kennedy D, et al. Toward a joint health and disease management program. Toronto hospitals partner to provide system leadership. Healthc Q 2009; 12:56-65.

11. Clark AJ. Central triage and improving the consultation process for patients with chronic pain [abstract 4A]. In: Proceedings of the 36th Annual Scientific Meeting of the Canadian Pain Society; 2015 May 20-23; Charlottetown. Pain Res Manag 2015;20:e30.

12. Leach P, Rutherford SA, King AT, et al. Generic waiting lists for routine spinal surgery. 7 R Soc Med 2004;97:119-20.

13. Sterne JA, Hernán MA, Reeves BC, et al. ROBINS-I: a tool for assessing risk of bias in non-randomised studies of interventions. BM7 2016;355:i4919.

14. Bichel A, Erfle S, Wiebe V, et al. Improving patient access to medical services: preventing the patient from being lost in translation. Healthc Q 2009;13:61-8.

15. Bungard TJ, Smigorowsky MJ, Lalonde LD, et al. Cardiac EASE (Ensuring Access and Speedy Evaluation): the impact of a single-point-of-entry multidisciplinary outpatient cardiology consultation program on wait times in Canada. Can 7 Cardiol 2009;25:697-702.

16. van den Heuvel B, Vair B, Porter G, et al. Patient compliance with a group model of care: the hernia clinic. Can 7 Surg 2012;55:259-63.

17. Schachter ME, Romann A, Djurdev O, et al. The British Columbia Nephrologists' Access Study (BCNAS): a prospective, health services interventional study to develop waiting time benchmarks and reduce wait times for outpatient nephrology consultations. BMC Nephrol 2013;14:182.

18. Wittmeier KDM, Restall G, Mulder K, et al. Central intake to improve access to physiotherapy for children with complex needs: a mixed methods case report. BMC Health Serv Res 2016;16:455.

19. Goodsall TM, Haskins R, Bennetts K, et al. A single-entry model for clinical triaging reduces wait time and improves key performance indicators of service delivery [abstract]. 7 Gastroenterol Hepatol 2017;32(Suppl 2):161.

20. Ramchandani M, Mirza S, Sharma A, et al. Pooled cataract waiting lists: views of hospital consultants, general practitioners and patients. $\mathcal{F} \mathrm{R}$ Soc Med 2002;95:598-600.

21. Cipriano LE, Chesworth BM, Anderson CK, et al. An evaluation of strategies to reduce waiting times for total joint replacement in Ontario. Med Care 2008;46:1177-83.

22. Singh N, Brooke-Cowden GL, Whitehurst C, et al. The Auburn Elective Surgery Pilot Project. ANZ 7 Surg 2005;75:768-75.

23. Bungard TJ, Smigorowsky MJ, Lalonde LD, et al. Cardiac EASE (Ensuring Access and Speedy Evaluation): design of a single point of entry and a multidisciplinary team to reduce waiting times in the Canadian health care system. Healthc Manage Forum 2008;21:35-40.

24. Hazlewood G, Lupton T, Martin L, et al. The impact of a centralized referral system in rheumatolooy. 7 Rheumatol 2010;37:1288-9.

25. Assmus MA, De S, Schuler TD, et al. The "acute" stone clinic effect: improving healthcare delivery by reorganizing clinical resources. 7 Endourol 2017;31:1096-100.
26. Novak K, Veldhuyezen van Zanten S, Pendharker SR. Improving access in gastroenterology: the single point of entry model for referrals. Can 7 Gastroenterol 2013;27:633-5.

27. Harding KE, Leggat SG, Bowers B, et al. Reducing waiting time for community rehabilitation services: a controlled before-and-after trial. Arch Pbys Med Rehabil 2013;94:23-31.

28. Liddy C, Drosinis P, Keely E. Electronic consultation systems: worldwide prevalence and their impact on patient care-a systematic review. Fam Pract 2016;33:274-85.

29. Vimalananda VG, Orlander JD, Afable MK, et al. Electronic consultations (e-consults) and their outcomes: a systematic review. $7 \mathrm{Am}$ Med Inform Assoc 2020;27:471-9.

30. Wiltsey Stirman S, Kimberly J, Cook N, et al. The sustainability of new programs and innovations: a review of the empirical literature and recommendations for future research. Implement Sci 2012;7:17.

31. Rogers Van Katwyk S, Hoffman SJ, Mendelson M, et al. Strengthening the science of addressing antimicrobial resistance: a framework for planning, conducting and disseminating antimicrobial resistance intervention research. Health Res Policy Syst 2020;18:60.

Affiliations: Faculty of Medicine (Milakovic), Leslie Dan Faculty of Pharmacy (Tadrous), Department of Family and Community Medicine (Ivers) and Institute of Health Policy, Management and Evaluation (Ivers), University of Toronto; The Peter Gilgan Centre for Women's Cancers (Corrado) and Women's College Research Institute (Tadrous, Ivers), Women's College Hospital, Toronto, Ont.; Faculty of Medicine (Nguyen), Western University, London, Ont.; Faculty of Medicine (Vuong), University of Queensland, Brisbane, Australia

Contributors: All of the authors contributed to conception and design of the study and to acquisition, analysis and interpretation of the data. Milica Milakovic led the process of manuscript preparation, with substantive contributions from Ann Marie Corrado, Mina Tadrous, Mary Nguyen, Sandra Vuong and Noah Ivers. All of the authors gave final approval of the version to be published and agreed to act as guarantors of the work.

Funding: Ann Marie Corrado is supported by the Peter Gilgan Centre for Women's Cancers at Women's College Hospital, in partnership with the Canadian Cancer Society. Noah Ivers is supported as the Canada Research Chair in Implementation of Evidence-Based Practice and as a clinician scientist by the Department of Family and Community Medicine, University of Toronto.

Content licence: This is an Open Access article distributed in accordance with the terms of the Creative Commons Attribution (CC BY-NCND 4.0) licence, which permits use, distribution and reproduction in any medium, provided that the original publication is properly cited, the use is noncommercial (i.e., research or educational use), and no modifications or adaptations are made. See: https://creativecommons.org/licenses/ by-nc-nd/4.0/

Data sharing: All data contained in this manuscript are publicly available in the peer-reviewed publications included in the review.

Supplemental information: For reviewer comments and the original submission of this manuscript, please see www.cmajopen.ca/content/9/2/ E413/suppl/DC1. 